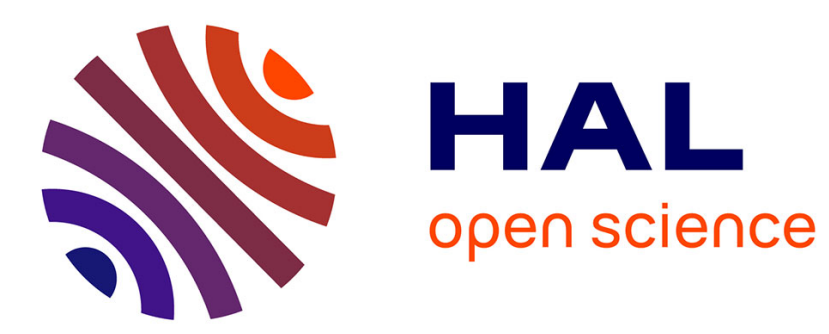

\title{
Functional characterization of ribosomal P1/P2 proteins in human cells
}

\author{
Francisco Martinez-Azorin, Miguel Remacha, Juan P.G. Ballesta
}

\section{To cite this version:}

Francisco Martinez-Azorin, Miguel Remacha, Juan P.G. Ballesta. Functional characterization of ribosomal P1/P2 proteins in human cells. Biochemical Journal, 2008, 413 (3), pp.527-534. 10.1042/BJ20080049 . hal-00478947

\section{HAL Id: hal-00478947 \\ https://hal.science/hal-00478947}

Submitted on 30 Apr 2010

HAL is a multi-disciplinary open access archive for the deposit and dissemination of scientific research documents, whether they are published or not. The documents may come from teaching and research institutions in France or abroad, or from public or private research centers.
L'archive ouverte pluridisciplinaire HAL, est destinée au dépôt et à la diffusion de documents scientifiques de niveau recherche, publiés ou non, émanant des établissements d'enseignement et de recherche français ou étrangers, des laboratoires publics ou privés. 


\title{
Functional characterization of ribosomal P1/P2 proteins in human cells
}

\author{
Francisco MARTINEZ-AZORIN, Miguel REMACHA and Juan P. G. BALLESTA
}

Centro de Biología Molecular “Severo Ochoa”, CSIC and UAM, Cantoblanco, E28049 Madrid, Spain.

Address correspondence to: Francisco Martínez-Azorín or Juan P. G. Ballesta, Centro de Biología Molecular "Severo Ochoa”, CSIC and UAM, Cantoblanco, E28049 Madrid, Spain; Tel.: +34 91196 4505; Fax: +34 91196 4420; E-mail: fmartinez@cbm.uam.es or jpgballesta@cbm.uam.es.

Short Title: P1/P2 depletion impairs ribosomal subunit joining

Keywords: P1/ P2/ proliferation/ ribosome/ RNAi/ subunit-joining

Abbreviations used: Dox, doxycycline; RNAi, RNA interference; shRNA, short hairpin RNA 


\section{SYNOPSIS}

The stalk is a large ribosomal subunit domain that regulates translation. In this study, the role of the ribosomal stalk $P$ proteins in modulating ribosomal activity has been investigated in human cells using RNAi. A strong down-regulation of P2 mRNA and a drastic reduction of $P 2$ protein in a stable human cell line was achieved using a Doxinducible system. Interestingly, the amount of $P 1$ protein was similarly reduced in these cells, in contrast to the expression of P1 mRNA. The loss of P1/P2 proteins produced a reduction in the growth rate of these cells, as well as an altered polysome pattern with reduced translation efficiency but without affecting the free $40 \mathrm{~S} / 60 \mathrm{~S}$ subunit ratio. A decrease in the ribosomal subunit joining capacity was also observed. These data indicate that P1/P2 proteins modulates cytoplasmic translation by influencing the interaction between subunits, thereby regulating the rate of cell proliferation. 


\section{INTRODUCTION}

Eukaryotic ribosomes contain four RNA molecules and approximately eighty proteins make up the small 40S and large 60S subunit. As key components of the translation machinery, ribosomes are central to many cellular processes [1]. Both in prokaryotes and eukaryotes, a lateral protuberance projects from the large subunit known as the ribosomal stalk [2]. This structure is an active ribosomal domain that directly interacts with the soluble translation factors, regulating their activity during the course of protein synthesis [3]. The eukaryotic ribosomal stalk is composed of ribosomal $\mathrm{P}$ proteins that usually exist as phosphoproteins in the cell. A $32 \mathrm{kDa}$ protein P0 is located at the stalk base and it forms a complex with several highly conserved 12 $\mathrm{kDa}$ proteins with very acidic isoelectric points (pI 3-4). On the basis of primary sequence similarities, these proteins are classified as P1 and P2 proteins [4], and an additional P3 group is also found in plants [5]. The stalk structure is formed by two heterodimers (P1/P2) 2 [6, 7], with P1 anchoring the complex to the P0 core ribosomal protein [8-10], which is in turn attached to 28S RNA [11]. These acidic ribosomal $\mathrm{P}$ proteins are the only molecules in the ribosome that exist in multiple units, although they are also found in a free state in the cytoplasm. In yeast [12, 13], plants [14], and mammals [15], the free proteins have been shown to participate in an exchange process between the ribosome-bound P1/P2 and a cytoplasmic pool of these proteins. Indeed, this exchange seems to be connected with ribosome-modulating mechanisms in which the ribosomal stalk participates in yeast [16]. Therefore, the stalk can exist in multiple configurations [17-19] and altering the P1/P2 composition of the stalk, mainly through its acidic P protein content [20] and/or the phosphorylation of these components [21, 22], can influence the activity of the ribosome and provoke global changes in protein synthesis $[19,23]$.

Most information on the possible regulatory functions of the ribosomal stalk has been obtained in Saccharomyces cerevisiae. Intrinsic difficulties to perform genetic manipulation in higher eukaryotes has made it difficult to investigate whether the stalk fulfils similar roles in mammalian cells. However, gene silencing with RNA interference (RNAi) enables the function of specific proteins to be investigated in established cell lines. Thus, permanent transfected cell lines expressing plasmid-encoded short hairpin RNAs (hRNAs) can lead to partial silencing of genes.

Using direct transient transfection of carcinoma cell lines with antisense oligonucleotides, approximately $60 \%$ silencing of the P2 protein has been achieved [24]. However, this level of inhibition is probably not sufficient to perform a convincing analysis of the function of the silenced proteins. Here, the importance of the stalk acidic proteins in translation has been investigated by generating stable human cell lines in which the P2 protein could be conditionally suppressed by up to $95 \%$ with RNAi. Using this approach, we show that RNAi expression directly reduces P2 mRNA and protein levels, which also results in a parallel decrease in the ribosomal P1 protein. Moreover, conditional depletion of P2 mRNA and protein also reduces the growth rate of the cells. We present evidence that the phenotype produced by P1/P2 depletion is due to the effects on the capacity of the 60S ribosomal subunit to associate with the 40S subunit. 


\section{METHODS}

\section{Cell lines and culture conditions}

The 293T (a human embryonic kidney cell line), TTR4 and SP23 cells were grown in Dulbecco's modified Eagle's medium (DMEM, Gibco Cell Culture Systems, Invitrogen) supplemented with $10 \%(\mathrm{v} / \mathrm{v})$ heat-inactivated foetal bovine serum (FBS), $100 \mathrm{IU} / \mathrm{ml}$ penicillin $\mathrm{G}$, and $100 \mu \mathrm{g} / \mathrm{ml}$ streptomycin. The cells were maintained in a humidified incubator at $37^{\circ} \mathrm{C}$ with $5 \%(\mathrm{v} / \mathrm{v}) \mathrm{CO}_{2}$, and they were passaged regularly at sub-confluence.

\section{Plasmid construction}

The target-specific siRNA duplexes were designed with the online siRNA Target Finder software (Ambion; http://www.ambion.com/techlib/misc/siRNA_finder.html), and the sequence selected to generate siRNA corresponds to the 369-387 region of the P2 mRNA sequence [25]. The pSUPERIOR.puro (OligoEngine) vector for inducible expression of siRNA was digested with BglII and HindIII, and the oligonucleotides (GATCCCCGGAGGAGTCTGAAGAGTCATTCAAGAGATGACTCTTCAGACTCCTCC TTTTTA

and AGCTTAAAAAGGAGGAGTCTGAAGAGTCATCTCTTGAATGACTCTTCAGACTCCT CCGGG) were ligated into the vector to generate pSUPERIOR.puro-P2. The 19-nucleotide target sequence for P2 is indicated in boldface within the oligonucleotide sequences.

\section{Generation of a stable TTR4 cell line}

Human $293 \mathrm{~T}$ cells were transfected with the tetracycline (TetR) repressor-expressing vector pcDNA6/TR (Invitrogen), which contains a blasticidin selection marker, using the jetPEI $^{\mathrm{TM}}$ (Qbiogene) transfection reagent according to the manufacturer's instructions. After 48 hours had passed, the cells were transferred to medium containing $10 \mu \mathrm{g} / \mathrm{ml}$ blasticidin hydrochloride (Sigma) for 2 weeks. Single clones were then isolated and expanded for an additional 2 months in media containing $10 \mu \mathrm{g} / \mathrm{ml}$ blasticidin, and analyzed by PCR.

\section{Generation of doxycycline-inducible P2 protein silencing cell line (SP23 clones)}

TTR4 cells were transfected with pSUPERIOR.puro-P2 plasmid and selected with 1 $\mu \mathrm{g} / \mathrm{ml}$ puromycin (Sigma) for 2 weeks. Single clones were isolated and expanded for an additional two months in the presence the antibiotic and analyzed by PCR. The cells (stable clones) were treated with different concentrations of doxycycline (Dox, Sigma) for the times indicated, and the P1 and P2 mRNA and protein they expressed was then analyzed.

\section{Western blot analysis}

After treatment with and without Dox for the different times indicated, subconfluent cell monolayers were washed twice with ice-cold PBS (Phosphate Buffered Saline) before they were removed from the dish by trypsinization. The cells were resuspended in a buffer containing 15 $\mathrm{mM}$ Tris- $\mathrm{HCl} \mathrm{pH} \mathrm{7.4,} 80 \mathrm{mM} \mathrm{KCl}, 5 \mathrm{mM} \mathrm{MgCl}, 1 \%$ (v/v) Triton X-100 and protease inhibitors ( $2.5 \mu \mathrm{g} / \mathrm{ml}$ leupeptin, pepstatin, bestatin, aprotinin, chymostatin and antipain (Sigma), and $1 \mathrm{mM}$ phenylmethylsulfonyl fluoride (PMSF)), and they were disrupted by 10 passages through a 20gauge syringe needle. SDS-PAGE gels $(12.5 \%(\mathrm{w} / \mathrm{v}))$ were loaded with $10 \mu \mathrm{g}$ of protein or $20 \mu \mathrm{l}$ of the sucrose fractions and the separated proteins were then transferred to PVDF membranes (Immobilon-P, Millipore), which were probed with a monoclonal antibody specific to the highly 
conserved carboxyl terminus of eukaryotic acidic P-proteins 3BH5 [26]. A horseradish peroxidase-conjugated rabbit anti-mouse antiserum was used as a secondary antibody. The amounts of P0, P1 and P2 protein were quantified from the Western-blots by scanning densitometry using NIH Image version 1.29 software. All results were calculated as the percentage of protein expression (P1 or P2 protein normalized to the P0 protein) in Dox-induced cells versus control cells.

\section{Real time quantitative RT-PCR analysis}

Total RNA was isolated using a RNeasy mini kit (Qiagen) according to the manufacturer's instructions, and the RNA recovered was quantified by measuring the absorbance at 260/280 nm using a Nanodrop ND-1000 spectrophotometer (NanoDrop Technologies). An equal amount of purified RNA was examined in triplicate from each sample in each experiment. Real-time quantitative reverse transcription polymerase chain reaction was performed using LightCycler RNA Master SYBR Green I (Roche) on the LightCycler 2.0 System (Roche). The primers used in this study were those retrieved from PrimerBank (http://pga.mgh.harvard.edu/primerbank/; PrimerBank IDs: P0 (16933546a1), P1 (4506669a1) and P2 (4506671a1)) and they were purchased from Isogen. The reaction was carried out in a 20 $\mu \mathrm{l}$ volume and it included an initial reverse transcription at $61^{\circ} \mathrm{C}$ for $20 \mathrm{~min}$, followed by an incubation at $95^{\circ} \mathrm{C}$ for $30 \mathrm{~s}$ and 45 amplification cycles of: $1 \mathrm{~s}$ at $95^{\circ} \mathrm{C}$ followed by $5 \mathrm{~s}$ at $60^{\circ} \mathrm{C}$ and finally $7 \mathrm{~s}$ at $72^{\circ} \mathrm{C}$. The products amplified from each reaction were analyzed using LightCycler Relative Quantification Software v.1.0 (Roche). PCR efficiencies (E) were calculated based on the slope of the relationship between the log input RNA versus the threshold cycle $\left(C_{t}\right.$ is defined as the point where the fluorescence exceeds the background threshold level and it is determined as the second derivative maximum):

$$
E=10^{-(1 / \text { slope })}
$$

The relative expression between Dox-treated and control cells was quantified by the Pfaffl method [27] using P0 as a reference gene:

$$
\text { Relative expression }=\mathrm{E}_{\text {target }(\mathrm{P} 1 \text { or } \mathrm{P} 2)} \Delta \mathrm{Ct}\left(\text { Control-Dox) } * \mathrm{E}_{\text {reference }(\mathrm{P} 0)}^{\Delta \mathrm{Ct}(\text { Dox-Control) }}\right.
$$

The following equation was used to determine the relative quantification of a target gene in comparison to a reference gene (P0) in control cells:

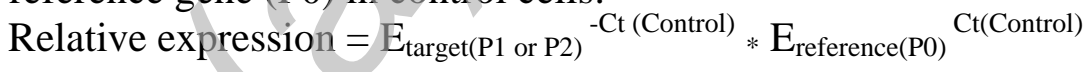

\section{Cell proliferation assay}

To analyze cell proliferation, 5 x $10^{5}$ cells were cultured for 3 days before exposing them to different concentrations of Dox. The number of cells was counted daily using a Neubauer cell counter and the doubling time (DT) was calculated from the regression analysis of the growth curves ( $\mathrm{N}=\mathrm{N}_{0} \mathrm{e}^{\mathrm{kt}}$, where $\mathrm{t}$ indicates the length of time and $\mathrm{N}$ denotes the cell number), where $\mathrm{DT}=\ln 2 / \mathrm{k}$, and $\mathrm{k}$ is a proliferation rate coefficient that was estimated individually for each exponentially growth curve.

\section{Cell viability}

The effect of silencing P2 by Dox-induction on cell viability was assessed using a trypan blue exclusion assay. Prior to trypsinization, medium was collected from all the cultures in order to include any cells that had detached during treatment. Cells were then combined with $0.4 \%$ trypan blue at a 1:1 ratio and counted to assess their viability. 


\section{Flow cytometry}

Cells were harvested after the treatments and time periods indicated, and they were analyzed by flow cytometry. The cells were fixed with methanol, treated with $50 \mu \mathrm{g} / \mathrm{ml}$ Ribonuclease A and stained with $50 \mu \mathrm{g} / \mathrm{ml}$ of propidium iodide (PD Pharmigen), and their DNA content was analyzed on a FACS Calibur flow cytometer (BD Biosciences). For each sample 20,000 cells were used and the data were analyzed with the CELLQuest software (BecktonDickinson). The percentage of cells in each phase of the cell cycle was determined as a ratio of the fluorescent area of the appropriate peaks to the total fluorescent area.

\section{Analysis of polysomes}

Ribosome profiles were prepared from a total of $2 \times 10^{7}$ cells at $80 \%$ confluence, which were washed with ice-cold PBS containing $100 \mu \mathrm{g} / \mathrm{ml}$ cycloheximide (Sigma) to block ribosomes in the elongation step. Cells were lysed with buffer A (15 mM Tris-HCl pH 7.4, 80 $\mathrm{mM} \mathrm{KCl}, 5 \mathrm{mM} \mathrm{MgCl} 2$ and $100 \mu \mathrm{g} / \mathrm{ml}$ cycloheximide), containing 1\% (v/v) Triton X-100, 40 $\mathrm{U} / \mathrm{ml}$ RNasin and protease inhibitors (see above). Cytoplasmic extracts were obtained after centrifugation at $15,000 \mathrm{x}$ g for $30 \mathrm{~min}$ at $4^{\circ} \mathrm{C}$, they were loaded onto a linear 10 to $50 \%(\mathrm{w} / \mathrm{v})$ sucrose gradient in buffer A and then centrifuged at $270,000 \mathrm{x}$ g for $2 \mathrm{~h} 15 \mathrm{~min}$ at $4^{\circ} \mathrm{C}$. Gradients were fractionated by upward displacement with $87 \%(\mathrm{v} / \mathrm{v})$ glycerol in an ISCO density gradient fractionator, and the absorbance at $260 \mathrm{~nm}$ was monitored continuously using an ISCO UA-5 UV monitor. The area under the profile in each peak (subunits, monosomes and polysomes) was calculated and the background signal was subtracted. The overall translation efficiency was calculated as the area under the curve representing two or more ribosomes (polysomal RNA) divided by the total area under the curve [28]. The average number of ribosomes per mRNA in the polysomes (with two or more ribosomes attached) was estimated from the polysome profiles, summing the product of the area of each peak multiplied by the number of ribosomes at that peak, and dividing by the total area of polysomes. The relative ribosome content was calculated as the area under the curve representing ribosomes (one or more ribosomes) divided by the area under the subunit peaks (40S and 60S).

In ribosome dissociation experiments, cycloheximide was omitted from all the buffers and the $\mathrm{KCl}$ concentration in the cytoplasmic extracts obtained after centrifugation was increased to $0.5 \mathrm{M}$ (high salt). Ribosomal subunits were resolved by centrifugation at 270,000 x $\mathrm{g}$ for $3 \mathrm{~h}$ $30 \mathrm{~min}$ at $4^{\circ} \mathrm{C}$ on a 10 to $30 \%(\mathrm{w} / \mathrm{v})$ sucrose gradient containing $15 \mathrm{mM}$ Tris-HCl $\mathrm{pH}$ 7.4, 500 $\mathrm{mM} \mathrm{KCl}$ and $5 \mathrm{mM} \mathrm{MgCl}_{2}$.

In the steady-state subunit joining analysis, the cells were lysed with buffer B (15 mM Tris-HCl pH 7.4, $80 \mathrm{mM} \mathrm{KCl}$ and 0, 1, 2.5 or $5 \mathrm{mM} \mathrm{MgCl}_{2}$ ), containing 1\% (v/v) Triton X-100, $40 \mathrm{U} / \mathrm{ml} \mathrm{RNasin}$ and protease inhibitors. The lysates were loaded onto a linear 10 to 30\% (w/v) sucrose gradient in buffer B, centrifuged at 270,000 x g for $3 \mathrm{~h} 30 \mathrm{~min}$ at $4^{\circ} \mathrm{C}$ and fractionated. To quantify the association between ribosomal subunits from either control and P1/P2-depleted ribosomes, the peak areas from the sucrose gradient profiles were calculated:

$\%$ subunit association $=100 *$ area $80 \mathrm{~S}$ peak $/($ area $(40 \mathrm{~S}+60 \mathrm{~S}+80 \mathrm{~S})$ peaks $)$

\section{Statistical analysis}

The results were analyzed using the Student's t test and p values of less than 0.05 were considered statistically significant. 


\section{RESULTS}

\section{Selection of stable doxycycline (Dox)-inducible $P$ protein silencing cell lines}

TTR4 cells transfected with pSUPERIOR.puro vector (OligoEngine) were selected with puromycin. Stably transfected SP14 (Supplementary online material) and SP23 cells containing the P1 and P2 constructs were assayed by exposing them to doxycycline (Dox, $10 \mu \mathrm{g} / \mathrm{ml}$ ) for 2 days. Among the SP14 transfectants only one clone showed an $~ 60 \%$ reduction in P1 protein and a parallel reduction in P2 protein of $\sim 40 \%$ (Figure 1S, Supplementary online material). In contrast, three SP23 transfectants showed a reduction of P2 protein levels after Dox exposure above 90\% (clones SP23-5, SP23-8 and SP23-10, Figure 1A) and notably, the amount of P1 proteins was also reduced when P2 was silenced in these clones. The effect of different Dox concentrations on P2 accumulation was tested by western blotting of SP23-5 cells (Figure 1B) and accordingly, Dox concentrations as low as $0.05 \mu \mathrm{g} / \mathrm{ml}$ significantly reduced P2 accumulation in these cells. Thus, the SP23-5 clone was used in the following experiments as a Dox-inducible P2 silencing cell line to induce P1/P2 proteins depletion.

\section{In human cells, $\mathbf{P 1}$ Protein is unstable in the absence of $\mathbf{P} 2$}

To quantify stalk protein depletion, SP23-5 cells were treated with 0 (control), 0.1 or 10 $\mu \mathrm{g} / \mathrm{ml}$ Dox for four days and the accumulation of P0, P1 and P2 proteins was assessed. Since the amount of P0 protein remained unchanged, this protein was subsequently used to normalize the values of P1 and P2 protein. A mean decrease in P2 protein of 90\% and 95\% was observed in cells induced with either 0.1 or $10 \mu \mathrm{g} / \mathrm{ml}$ Dox, respectively (Figure 1C). Significantly, in these same cells, the amount of $\mathrm{P} 1$ protein also fell by $70 \%$ or $85 \%$, respectively (Figure 1C; see also Figure 1A and 1B). Thus, both acidic stalk proteins were depleted in these cells following Doxinduction.

To confirm that P2 expression was indeed silenced, the individual mRNAs present were measured by real time RT-PCR (Figure 1D). Within 4 days of Dox induction, there was a dramatic decrease in P2 mRNA transcripts (Figure 1D), with a depletion of P2 mRNA above $70 \%$ in the presence of $0.1 \mu \mathrm{g} / \mathrm{ml}$ Dox and of around 90\% with $10 \mu \mathrm{g} / \mathrm{ml}$ Dox. Therefore, the loss of the P2 protein was correlated with a decrease in the P2 mRNA available following exposure to Dox. By contrast, the amount of P1 mRNA expressed, which is notably higher than that of P2 mRNA in the controls (P1mRNA/P0mRNA $10.4 \pm 5.8$; P2mRNA/P0mRNA $0.7 \pm$ 0.3 ), is even higher after Dox treatment, suggesting that cells try to compensate for P1 protein depletion by increasing RPLP1 gene transcription.

\section{Depletion of P1/P2 proteins reduces the proliferative capacity of the induced cells}

The number of cells was monitored in order to analyze the effects of suppression of P1/P2 on cell proliferation (Figure 2). When the SP23-5 cells were cultured with Dox at different concentrations (from 0.1 to $10 \mu \mathrm{g} / \mathrm{ml}$ ), their capacity to proliferate was significantly diminished when compared with the control, uninduced-cells. Moreover, upon the removal of Dox the proliferation of the SP23-5 cells recovered to control levels (Figure 2A). In order to quantify these changes, the doubling times (DT) of the cells was calculated from the growth curves (Figure 2B). Thus, the DT of the SP23-5 cells increased from $21.9 \pm 0.2 \mathrm{~h}$ to $44.7 \pm 2.9 \mathrm{~h}$ following P1/P2 depletion on exposure to $0.1 \mu \mathrm{g} / \mathrm{ml}$ Dox, the concentration used in the following experiments. This low concentration of Dox $(0.1 \mu \mathrm{g} / \mathrm{ml})$ had no effect on the proliferation of TTR4 cells (data not shown). When Dox was removed from the media, the DT returned to 
$29.4 \pm 1.6 \mathrm{~h}$ after 6 days or to $22.4 \pm 1.9 \mathrm{~h}$ after 12 days, indicating that the effect of $\mathrm{P} 1 / \mathrm{P} 2$ depletion on the rate of cell growth was reversible. To test whether the suppression of the acidic stalk proteins induced by Dox-could also be reverted, a time course study of P2 silencing was performed. The kinetics of P2 silencing was examined in cells by western blotting, following a similar time course to the cell growth data (Figure 2C). Therefore, P2 depletion and its effect on cell growth is inducible and reversible.

\section{Depletion of P1/P2 proteins does not affect cell viability or the proportion of cells in the different phases of the cell cycle}

The reduced growth of SP23-5 cells following P1/P2 depletion prompted us to evaluate the viability of the cells following Dox induction. At all concentrations and time points evaluated, the viability of P1/P2-depleted cells remained above $90 \%$ and this did not differ significantly from that of the control cells (91 $\pm 4 \%$, Figure $3 \mathrm{~A})$. Thus, there was no indication that $\mathrm{P} 1$ and $\mathrm{P} 2$ proteins depletion induced cell death.

The effect of P1/P2 depletion on the cell cycle was also evaluated after a 4 day induction of SP23-5 cells with $0.1 \mu \mathrm{g} / \mathrm{ml}$ Dox. There was clearly no difference between the number of cells in the different phases of the cell cycle in control and P1/P2-depleted cells (Figure 3B). Therefore, acidic stalk proteins depletion did not affect the distribution of the cells in the distinct phases of the cell cycle. Furthermore, the apoptotic cells identified (subG0 population) were 6\% in both groups, confirming that there was no increase in cell death following P1 and P2 proteins depletion.

\section{Effect of P1/P2 depletion on translation efficiency}

The polysome profiles were examined to determine if the decreased growth rate of P1/P2depleted cells was due to a defect in some aspect of ribosome synthesis, assembly or function. In these assays, the number of ribosomes found within the polysomal mRNA fraction (mRNA containing two or more ribosomes) is a reflection of de novo protein synthesis [28]. The control ribosomal profile shows the translating polysomes (the $80 \mathrm{~S}$ monosome peak harbors translating single $80 \mathrm{~S}$ ribosomes and inactive couples), and free 60S and 40S subunits, respectively (Figure 4A, left panel). In comparison to the control cells, the P1/P2-depleted cells show a reduction in the total amount of monosomes and polysomes but not in the number and the relative proportion of the polysome peaks (Figure 4A, right panel). Furthermore, the reduction in the 80S peak was accompanied by the appearance of halfmers $[29,30]$ and an increase in the amount of free 60S subunits. These data, especially the obvious decrease in the amount of polysomes, suggest that the decreased growth rate of P1/P2-depleted cells was compatible with the reduced rate of translation initiation [31].

The proteins extracted from gradient fractions were resolved by SDS-PAGE and analyzed in western blots (Figure 4B). The P0 protein clearly co-sedimented with free 60S, 80S and polysomes, and it was absent from cytosolic and free 40S fractions from control and Dox-treated cells. By contrast, free P1 and P2 proteins were detected in the cytosolic fractions as well as in the particles where P0 was detected. P1 and P2 proteins were depleted in all ribosome containing fractions (4-10) in Dox-induced cells when compared to control cells, indicating the presence of active ribosomes lacking P1 and/or P2 proteins in the polyribosomes of P1/P2-depleted cells. It is interesting to note that the amount of $\mathrm{P} 1$ protein found at the top of the gradient, which corresponds to the free cytoplasmic pool, is much less affected in the Dox-treated cells. 
The overall translation efficiency is defined as the proportion of rRNA participating in polysomes [28]. Thus, to determine whether depletion of P1/P2 proteins altered translational efficiency, the amount of rRNA actively involved in translation (associated with polysomes) was measured. In control cells, $54 \pm 3 \%$ of RNA was in polysomes and this dropped to $43 \pm 4 \%$ following acidic proteins depletion (Figure 4C). Thus, there was a reduction in global translation of $\sim 20 \%$.

An analysis of the polysome profiles showed that the depletion of $\mathrm{P} 1 / \mathrm{P} 2$ proteins did not change the distribution of the polysomal mRNA (Figure 4A). Thus, the average number of ribosomes per translated transcript (mRNAs containing two or more ribosomes) was not altered (5.0 \pm 0.1 in both cases, Figure 4D). In contrast, the relative ribosomal content, estimated from the polysome profiles as the ratio of ribosomes (monosomes and polysomes) and subunits (40S and 60S), fell from $5.2 \pm 0.3$ to $3.4 \pm 0.4$ (Figure $4 \mathrm{E}$ ), indicating a defect in the equilibrium between ribosomes and subunits.

\section{The depletion of P1/P2 proteins makes ribosomal subunit joining less efficient}

The total amount of $40 \mathrm{~S}$ and $60 \mathrm{~S}$ ribosomal subunits was analyzed in control and P1/P2depleted cells after treatment with $0.1 \mu \mathrm{g} / \mathrm{ml}$ Dox for 4 days. The cell extracts were treated with high- $\mathrm{K}^{+}(500 \mathrm{mM} \mathrm{KCl})$ in the absence of cycloheximide in order to fully dissociate the 80S ribosomes and in this way, the total amount of the 40S and 60S ribosomal subunits could be estimated [32]. P1/P2 proteins depletion did not affect the steady-state levels of 40S and 60S ribosomal subunits (Figure 5A).

The decrease in the relative ribosome content (Figure 4E), the production of halfmers in $\mathrm{P} 1 / \mathrm{P} 2-$ depleted cells and the accumulation of free 60S subunits (Figure 4A) while the overall subunit stoichiometry remains unchanged (Figure 5A), strongly suggested that the low levels of P1 and P2 proteins made subunit joining less efficient. To confirm this suggestion, the steadystate association capacity of $40 \mathrm{~S}$ and $60 \mathrm{~S}$ ribosomal subunits in control and P1/P2-depleted cell extracts was tested by sucrose gradient centrifugation at different concentrations of $\mathrm{Mg}^{2+}$ (Figure 5B). As expected, 80S ribosomes totally dissociated in the absence of $\mathrm{Mg}^{2+}$ in both cell types tested. The $40 \mathrm{~S}$ to $60 \mathrm{~S}$ ratio showed average values of $2.8 \pm 0.3$ and $2.6 \pm 0.3$ for control and Doxtreated cells, respectively, confirming that the steady-state ratio of $40 \mathrm{~S}$ and $60 \mathrm{~S}$ subunits was not affected by P1/P2 depletion. Increasing the $\mathrm{Mg}^{2+}$ concentration in the gradients from 1 to $5 \mathrm{mM}$ highlighted the different degree of subunit association, which was always lower in the Doxtreated sample than in the corresponding controls (Figure 5B). This effect was most evident when the proportion of associated subunits was plotted as a function of the magnesium concentration (Figure 5C). As expected, the degree of association increases in function of the $\mathrm{Mg}^{2+}$ concentration for both control and P1/P2-depleted cells. However, the association capacity of the ribosomes from P1/P2-depleted cells was notably lower $(\sim 30 \%)$ than that of the control cells. Hence, it seems clear that the lack of P1 and P2 proteins clearly reduced the capacity of the $60 \mathrm{~S}$ subunit to form $80 \mathrm{~S}$ ribosomes in the cell extracts.

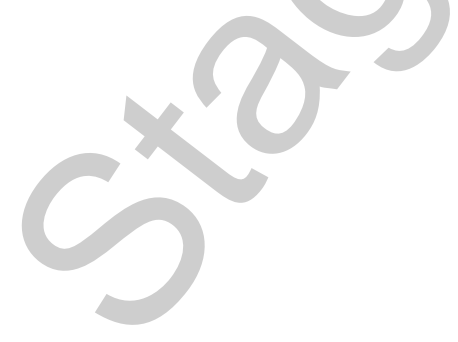




\section{DISCUSSION}

Through the Dox-induced expression of short-hairpin RNAs (shRNAs) targeted to mRNA encoding stalk ribosomal P2 protein, both P2 transcripts and protein have been reduced in stably transfected human cells to levels below $10 \%$ of those in control cells. This depletion of P2 was associated with a similar decrease of its partner ribosomal stalk component, the P1 protein, without a parallel reduction in P1 mRNA, which rather increased significantly. These results indicate that $\mathrm{P} 1$ was unstable in the absence of $\mathrm{P} 2$ in human cells, consistent with data obtained in Saccharomyces cerevisiae. In yeast, free P1 protein is highly unstable, with a halflife of a few minutes, while P2 has a half-life of several hours. The yeast P1 protein is degraded by a proteosome-independent mechanism and its association with $\mathrm{P} 2$ protein protects it from degradation [33]. However, while P1 protein is not detected in yeast strains that lack the P2 protein [34], in human cells a significant amount of P1 is found in the supernatant when P2 is silenced in cells, considerably more than the residual amount of P2 detected (Figure 4B). This difference could be attributed to a higher intrinsic resistance to degradation of the human protein, possibly due to the lack of a serine at the second position in the amino end of the human P1, an important residue in the yeast P1 degradation signal ([33], Nusspaumer, Briceño, Remacha and Ballesta, unpublished results). Alternatively, the large excess of P1 mRNA detected in the SP23 cell line (P1mRNA >> P0mRNA P2mRNA), which is not seen in yeast [33], could result in an excessive accumulation of protein that might saturate the degradation system. The fact that P1 protein can be detected in a yeast strain lacking P2 protein when overexpressed but not when it is expressed only from the endogenous gene [17] supports this possibility. However, further experiments will be required to determine how this phenomenon can be explained. Indeed, in contrast to yeast, where P2 proteins were not affected by P1 deficiency [33], the amount of P2 protein in human cells was reduced when P1 was depleted (Figure 1S), indicating that P2 was less stable in absence of P1.

As in yeast [10], human ribosomal P proteins preferentially form P1-P2 heterodimers [35] that attach to $\mathrm{P} 0$ through the $\mathrm{P} 1$ protein [9], forming the pentameric $\mathrm{P} 0-(\mathrm{P} 1-\mathrm{P} 2)_{2}$ structure on the ribosome [20,36]. The interaction between $\mathrm{P} 1$ and $\mathrm{P} 2$ to form the P1-P2 heterodimer seems to be a crucial step for efficient assembly of the functional GTPase-associated centre, and P1 or P2 alone fails to bind efficiently to P0 [37]. The results presented here are consistent with the assembly model whereby the soluble heterodimers P1-P2 bind to P0 on the ribosome. For this reason, P1 that is more resistant to degradation accumulates in the cytosol when the levels of P2 are too low to form heterodimers, even though the ribosomes are defective in P1/P2 proteins.

As found previously in S. cerevisiae [19], we can conclude that the ribosomal stalk P1 and $\mathrm{P} 2$ proteins are not a prerequisite for ribosome activity and protein synthesis in human cells. Indeed, particles lacking both proteins are incorporated into polysomes (Figure 4A and 4B, right panels). However, the absence of these ribosomal components does have consequences for the cell. Recent studies have shown that ribosome synthesis is intimately linked with cell growth and the regulation of the cell cycle [38]. Although the details of this association are not yet understood, it is clear that the quality and quantity of ribosomes directly determine the growth rate of cells and by extension, the timing of cell division. Indeed, a reduction in the cell growth rate was the most obvious consequence of the absence of acidic P proteins in cells, with doubling times increasing from 22 to 45 hours. This inhibition was not correlated with a loss of cell viability and there was no evidence of cell death when the subG0 phase in the cell cycle was evaluated, indicating that the decrease in cell growth was not due to cytotoxicity. Moreover, there was no arrest of P1/P2-depleted cells at any specific phase of the cell cycle but rather, they 
seemed to progress through it at a slower rate. It is therefore conceivable that the overall reduction in mRNA translation observed in cells lacking P1/P2 proteins affects genes involved in the cell cycle. This would explain the reduced rate of cell cycle progression. However, these effects are reversible and upon re-establishing P2 expression the growth rate returns to normal.

After P1/P2 proteins depletion, the polysome profiles show an increase in the 60S peak as well as a reduction in 80S and polysome peaks, without any apparent effect on average number of ribosome per mRNA transcript. In addition, halfmers appear in polyribosomes due to a latestage translational initiation defect in which 43S preinitiation complexes are attached to an mRNA that already contains at least one translating 80S ribosome but lacks the corresponding 60S subunit [29]. These structures were first described in vitro in the rabbit reticulocyte translation system after sodium fluoride treatment [39], and in vivo in Ehrlich ascites cells treated with anisomycin [40]. Halfmers may reflect a stoichiometric ribosomal subunit imbalance caused by a reduced supply of 60S subunits, resulting in an excess of 40S over 60S subunits [4143]. Alternatively, halfmers may be generated without altering the subunit balance from impaired translation initiation, whereby inhibitors of translation initiation [29] or defective ribosomal components [30, 31, 44, 45] prevent subunit joining. Thus, halfmers are indicative of a defect in ribosomal subunit joining [46], and coupled to the decrease in the amount of polysomes, their presence is compatible with defects at the level of translation initiation caused by depletion in $\mathrm{P} 1 / \mathrm{P} 2$ proteins. However, the reduction in the average number of ribosome per translated transcript when initiation is blocked [28, 47, 48] was not detected in our system and thus, it is possible that acidic proteins depletion also affects other translation steps. This is not unexpected, since bacterial stalk acidic proteins influence the activity of initiation, elongation and termination factors [3, 49].

The ratio between free $60 \mathrm{~S}$ and $40 \mathrm{~S}$ ribosomal subunits in polyribosome profiles revealed an increase in the amount of free $60 \mathrm{~S}$ ribosomal subunits relative to free $40 \mathrm{~S}$ subunits in P1/P2depleted cells. However, when the 40S to 60S ratio was more closely examined after ribosome dissociation on sucrose gradients with either high- $\mathrm{K}^{+}$or in the absence of $\mathrm{Mg}^{2+}$, no changes were detected. These results indicate that the biogenesis of the subunits was not affected by P1/P2 proteins depletion and thus, a subunit imbalance is unlikely to be the cause of halfmer formation. Furthermore, the polysome profile of P1/P2-depleted cells showed a significant reduction in the relative ribosome content (accumulation of subunits). Consequently, the absence of P1/P2 proteins could produce defective steady-state subunit joining, and indeed, a decrease in ribosomal subunit association in P1/P2-depleted cells was directly confirmed by sedimentation analysis at different $\mathrm{Mg}^{2+}$ concentrations. Thus, 60S subunits depleted of acidic proteins were

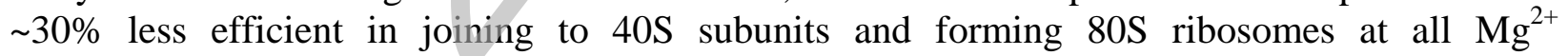
concentrations tested. This illustrates the importance of the contribution of P1/P2 proteins to the subunit joining activity. In addition, a global decrease in translation efficiency that would be expected to contribute to a depletion of many proteins could account for the reduced growth rate of the P1/P2-depleted cells. This presumably results from a reduction in the rate at which ribosomal subunits can be loaded onto mRNA, as a consequence of the impaired association of ribosomes depleted of $\mathrm{P} 1 / \mathrm{P} 2$ proteins. Thus, the $\mathrm{P} 1 / \mathrm{P} 2$ content of the stalk could modulate the joining of the $60 \mathrm{~S}$ ribosomal subunit. Although it is widely accepted that translation initiation is the rate-limiting step for translation and our results show that depletion of P1/P2 proteins significantly affect the ribosomal subunit-joining, we can not rule out an additional effect of the $\mathrm{P} 1 / \mathrm{P} 2$ depletion on the elongation step of translation.

Data obtained from $S$. cerevisiae strongly suggest that the ribosomal stalk could function as a translational regulator of specific mRNAs [19]. The results presented here indicate that this 
regulation could be achieved by modulating ribosomal subunit association. In agreement with this idea, several studies have indicated that translation can be regulated at the subunit joining stage [50-52].

\section{ACKNOWLEDGMENTS}

We thank M.C. Fernández Moyano for expert technical assistance. This work was supported by the Ministerio de Educación y Ciencia, Spain (BFU2006-00365 to J.P.G.B., BFU2004-03079 to M.R.); Fundación Ramón Areces, Spain (to J.P.G.B.). 


\section{REFERENCES}

1 Doudna, J. A. and Rath, V. L. (2002) Structure and function of the eukaryotic ribosome: the next frontier. Cell 109, 153-156

2 Gomez-Lorenzo, M. G., Spahn, C. M., Agrawal, R. K., Grassucci, R. A., Penczek, P., Chakraburtty, K., Ballesta, J. P. G., Lavandera, J. L., Garcia-Bustos, J. F. and Frank, J. (2000) Three-dimensional cryo-electron microscopy localization of EF2 in the Saccharomyces cerevisiae 80S ribosome at 17.5 A resolution. EMBO J. 19, 2710-2718

3 Gonzalo, P. and Reboud, J. P. (2003) The puzzling lateral flexible stalk of the ribosome. Biol. Cell. 95, 179-193

4 Wool, I. G., Chan, Y. L., Glück, A. and Suzuki, K. (1991) The primary structure of rat ribosomal proteins $\mathrm{P} 0, \mathrm{P} 1$, and $\mathrm{P} 2$ and a proposal for a uniform nomenclature for mammalian and yeast ribosomal proteins. Biochimie 73, 861-870

5 Bailey-Serres, J., Vangala, S., Szick, K. and Lee, C. H. (1997) Acidic phosphoprotein complex of the 60S ribosomal subunit of maize seedling roots. Components and changes in response to flooding. Plant Physiol. 114, 1293-1305

6 Grela, P., Sawa-Makarska, J., Gordiyenko, Y., Robinson, C. V., Grankowski, N. and Tchorzewski, M. (2007) Structural properties of the human acidic ribosomal P proteins forming the P1-P2 heterocomplex. J Biochem (Tokyo)

7 Hagiya, A., Naganuma, T., Maki, Y., Ohta, J., Tohkairin, Y., Shimizu, T., Nomura, T., Hachimori, A. and Uchiumi, T. (2005) A mode of assembly of P0, P1, and P2 proteins at the GTPase-associated center in animal ribosome: in vitro analyses with P0 truncation mutants. J Biol Chem 280, 39193-39199

8 Zurdo, J., Parada, P., van den Berg, A., Nusspaumer, G., Jimenez-Diaz, A., Remacha, M. and Ballesta, J. P. (2000) Assembly of Saccharomyces cerevisiae ribosomal stalk: binding of P1 proteins is required for the interaction of P2 proteins. Biochemistry 39, 8929-8934

9 Gonzalo, P., Lavergne, J. P. and Reboud, J. P. (2001) Pivotal role of the P1 N-terminal domain in the assembly of the mammalian ribosomal stalk and in the proteosynthetic activity. J Biol Chem 276, 19762-19769

10 Guarinos, E., Remacha, M. and Ballesta, J. P. G. (2001) Asymmetric interactions between the acidic P1 and P2 proteins in the Saccharomyces cerevisiae ribosomal stalk. J. Biol. Chem. 276, 32474-32479

11 Uchiumi, T. and Kominami, R. (1992) Direct evidence for interaction of the conserved GTPase domain within 28 S RNA with mammalian ribosomal acidic phosphoproteins and L12. J Biol Chem 267, 19179-19185

12 Zinker, S. and Warner, J. R. (1976) The ribosomal proteins of Saccharomyces cerevisiae. Phosphorylated and exchangeable proteins. J. Biol. Chem. 251, 1799-1807

13 Sanchez-Madrid, F., Vidales, F. J. and Ballesta, J. P. G. (1981) Effect of phosphorylation on the affinity of acidic proteins from Saccharomyces cerevisiae for the ribosomes. Eur. J. Biochem. 114, 609-613

14 Nover, L., Munsche, D., Neumann, D., Ohme, K. and Scharf, K. D. (1986) Control of ribosome biosynthesis in plant cell cultures under heat-shock conditions. Ribosomal RNA. Eur J Biochem 160, 297-304 
15 Tsurugi, K. and Ogata, K. (1985) Evidence for the exchangeability of acidic ribosomal proteins on cytoplasmic ribosomes in regenerating rat liver. J. Biochem. 98, 1427-1431

16 Ballesta, J. P. G. and Remacha, M. (1996) The large ribosomal subunit stalk as a regulatory element of the eukaryotic translational machinery. Progr. Nucleic Acids Res. Mol. Biol. 55, 157-193

17 Ballesta, J. P. G., Guarinos, E., Zurdo, J., Parada, P., Nusspaumer, G., Lalioti, V. S., Perez-Fernandez, J. and Remacha, M. (2000) Structure of the Yeast Ribosomal Stalk. In The Ribosome: Structure, Function, Antibiotics, and Cellular Interactions. (Garrett, R. A., Douthwaite, S. R., Liljas, A., Matheson, A. T., Moore, P. B. and Noller, H. F., eds.), pp. 115-125, ASM Press, Washington, D.C.

18 Santos, C. and Ballesta, J. P. G. (1994) Ribosomal protein P0, contrary to phosphoproteins $\mathrm{P} 1$ and $\mathrm{P} 2$, is required for ribosome activity and Saccharomyces cerevisiae viability. J. Biol. Chem. 269, 15689-15696

19 Remacha, M., Jimenez-Diaz, A., Bermejo, B., Rodriguez-Gabriel, M. A., Guarinos, E. and Ballesta, J. P. G. (1995) Ribosomal acidic phosphoproteins P1 and P2 are not required for cell viability but regulate the pattern of protein expression in Saccharomyces cerevisiae. Mol. Cell. Biol. 15, 4754-4762

20 Guarinos, E., Santos, C., Sanchez, A., Qiu, D. Y., Remacha, M. and Ballesta, J. P. G. (2003) Tag-mediated fractionation of yeast ribosome populations proves the monomeric organization of the eukaryotic ribosomal stalk structure. Mol. Microbiol. 50, 703-712

21 Ballesta, J. P. G., Rodriguez-Gabriel, M. A., Bou, G., Briones, E., Zambrano, R. and Remacha, M. (1999) Phosphorylation of the yeast ribosomal stalk. Functional effects and enzymes involved in the process. FEMS Microbiol. Rev. 23, 537-550

22 Vard, C., Guillot, D., Bargis, P., Lavergne, J. P. and Reboud, J. P. (1997) A specific role for the phosphorylation of mammalian acidic ribosomal protein P2. J. Biol. Chem. 272, 20259-20262

23 Remacha, M., Jimenez-Diaz, A., Santos, C., Briones, E., Zambrano, R., RodriguezGabriel, M. A., Guarinos, E. and Ballesta, J. P. G. (1995) Proteins P1, P2, and P0, components of the eukaryotic ribosome stalk. New structural and functional aspects. Biochem. Cell Biol. 73, 959-968

24 Gardner-Thorpe, J., Ito, H., Ashley, S. W. and Whang, E. E. (2003) Ribosomal protein P2: a potential molecular target for antisense therapy of human malignancies. Anticancer Res. 23, 4549-4560

25 Rich, B. E. and Steitz, J. A. (1987) Human acidic ribosomal phosphoproteins P0, P1, and P2: analysis of cDNA clones, in vitro synthesis, and assembly. Mol. Cell. Biol. 7, 40654074

26 Vilella, M. D., Remacha, M., Ortiz, B. L., Mendez, E. and Ballesta, J. P. G. (1991) Characterization of the yeast acidic ribosomal phosphoproteins using monoclonal antibodies. Proteins L44/L45 and L44' have different functional roles. Eur. J. Biochem. 196, 407-414

27 Pfaffl, M. W. (2001) A new mathematical model for relative quantification in real-time RT-PCR. Nucleic Acids Res. 29, 2002-2007

28 Koritzinsky, M., Magagnin, M. G., van den Beucken, T., Seigneuric, R., Savelkouls, K., Dostie, J., Pyronnet, S., Kaufman, R. J., Weppler, S. A., Voncken, J. W., Lambin, P., Koumenis, C., Sonenberg, N. and Wouters, B. G. (2006) Gene expression during acute and prolonged hypoxia is regulated by distinct mechanisms of translational control. Embo J 25, 1114-1125 
29 Helser, T. L., Baan, R. A. and Dahlberg, A. E. (1981) Characterization of a 40S ribosomal subunit complex in polyribosomes of Saccharomyces cerevisiae treated with cycloheximide. Mol. Cell. Biol. 1, 51-57

30 Eisinger, D. P., Dick, F. A. and Trumpower, B. L. (1997) Qsr1p, a 60S ribosomal subunit protein, is required for joining of 40S and 60S subunits. Mol. Cell. Biol. 17, 5136-5145

31 Petitjean, A., Bonneaud, N. and Lacroute, F. (1995) The duplicated Saccharomyces cerevisiae gene SSM1 encodes a eucaryotic homolog of the eubacterial and archaebacterial L1 ribosomal proteins. Mol. Cell. Biol. 19, 5071-5081

32 Martin, T. E., Rolleston, F. S., Low, R. B. and Wool, I. G. (1969) Dissociation and reassociation of skeletal muscle ribosomes. J. Mol. Biol. 43, 135-149

33 Nusspaumer, G., Remacha, M. and Ballesta, J. P. G. (2000) Phosphorylation and Nterminal region of yeast ribosomal protein $\mathrm{P} 1$ mediate its degradation, which is prevented by protein P2. EMBO J. 19, 6075-6084

34 Remacha, M., Santos, C., Bermejo, B., Naranda, T. and Ballesta, J. P. (1992) Stable binding of the eukaryotic acidic phosphoproteins to the ribosome is not an absolute requirement for in vivo protein synthesis. J Biol Chem 267, 12061-12067

35 Tchorzewski, M., Boldyreff, B., Issinger, O. and Grankowski, N. (2000) Analysis of the protein-protein interactions between the human acidic ribosomal P-proteins: evaluation by the two hybrid system. Int. J. Biochem. Cell Biol. 32

36 Hanson, C. L., Videler, H., Santos, C., Ballesta, J. P. and Robinson, C. V. (2004) Mass spectrometry of ribosomes from Saccharomyces cerevisiae: implications for assembly of the stalk complex. J Biol Chem 279, 42750-42757

37 Shimizu, T., Nakagaki, M., Nishi, Y., Kobayashi, Y., Hachimori, A. and Uchiumi, T. (2002) Interaction among silkworm ribosomal proteins P1, P2 and P0 required for functional protein binding to the GTPase-associated domain of 28S rRNA. Nucleic Acids Res 30, 2620-2627

38 Rudra, D. and Warner, J. R. (2004) What better measure than ribosome synthesis? Genes Dev. 18, 2431-2436

39 Hoerz, W. and McCarty, K. S. (1969) Evidence for a proposed initiation complex for protein synthesis in reticulocyte polyribosome profiles. Proc Natl Acad Sci U S A 63, 1206-1213

40 van Venrooij, W. J., van Eenbergen, J. and Janssen, A. P. (1977) Effect of anisomycin on the cellular level of native ribosomal subunits. Biochemistry 16, 2343-2348

41 Moritz, M., Paulovich, A. G., Tsay, Y. F. and Woolford, J. L. J. (1990) Depletion of yeast ribosomal proteins L16 or rp59 disrupts ribosome assembly. J. Cell Biol. 111, 2261-2274

42 Becam, A. M., Nasr, F., Racki, W. J., Zagulski, M. and Herbert, C. J. (2001) Ria1p (Ynl163c), a protein similar to elongation factors 2, is involved in the biogenesis of the 60S subunit of the ribosome in Saccharomyces cerevisiae. Mol. Genet. Genomics 266, 454-462

43 Rotenberg, M. O., Moritz, M. and Woolford, J. L., Jr. (1988) Depletion of Saccharomyces cerevisiae ribosomal protein L16 causes a decrease in 60S ribosomal subunits and formation of half-mer polyribosomes. Genes Dev 2, 160-172

44 Pachler, K., Karl, T., Kolmann, K., Mehlmer, N., Eder, M., Loeffler, M., Oender, K., Hochleitner, E. O., Lottspeich, F., Bresgen, N., Richter, K., Breitenbach, M. and Koller, L. (2004) Functional interaction in establishment of ribosomal integrity between small subunit protein rpS6 and translational regulator rpL10/Grc5p. FEMS Yeast Res. 5, 271280 
45 Baronas-Lowell, D. M. and Warner, J. R. (1990) Ribosomal protein L30 is dispensable in the yeast Saccharomyces cerevisiae. Mol. Cell. Biol. 10, 5235-5243

46 Fringer, J. M., Acker, M. G., Fekete, C. A., Lorsch, J. R. and Dever, T. E. (2007) Coupled release of eukaryotic translation initiation factors $5 \mathrm{~B}$ and $1 \mathrm{~A}$ from $80 \mathrm{~S}$ ribosomes following subunit joining. Mol Cell Biol 27, 2384-2397

47 Petersen, N. S. and McLaughlin, C. S. (1974) Polysome metabolism in protein synthesis mutants of yeast. Mol Gen Genet 129, 189-200

48 Greenberg, J. R., Phan, L., Gu, Z., deSilva, A., Apolito, C., Sherman, F., Hinnebusch, A. G. and Goldfarb, D. S. (1998) Nip1p associates with 40 S ribosomes and the Prt1p subunit of eukaryotic initiation factor 3 and is required for efficient translation initiation. J Biol Chem 273, 23485-23494

49 Helgstrand, M., Mandava, C. S., Mulder, F. A., Liljas, A., Sanyal, S. and Akke, M. (2007) The ribosomal stalk binds to translation factors IF2, EF-Tu, EF-G and RF3 via a conserved region of the L12 C-terminal domain. J Mol Biol 365, 468-479

50 Ostareck, D. H., Ostareck-Lederer, A., Shatsky, I. N. and Hentze, M. W. (2001) Lipoxygenase mRNA silencing in erythroid differentiation: The 3'UTR regulatory complex controls 60S ribosomal subunit joining. Cell 104, 281-290

51 Johnstone, O. and Lasko, P. (2004) Interaction with eIF5B is essential for Vasa function during development. Development 131, 4167-4178

52 Searfoss, A., Dever, T. E. and Wickner, R. (2001) Linking the 3' poly(A) tail to the subunit joining step of translation initiation: relations of Pab1p, eukaryotic translation initiation factor 5b (Fun12p), and Ski2p-Slh1p. Mol Cell Biol 21, 4900-4908 


\section{FIGURE LEGENDS}

Figure 1 RNAi-mediated silencing of P2 expression in SP23-5 cells

(A) Stable clones carrying inducible P2 shRNA before (-) or after (+) induction with Dox for 2 days. (B) SP23-5 cells were exposed to the Dox concentrations indicated for 3 days. The position of the three stalk P proteins, as well as that of the molecular mass markers (KDa), is indicated. (C) SP23-5 cells were incubated with 0 (control), 0.1 or $10 \mu \mathrm{g} / \mathrm{ml}$ Dox for 4 days. Proteins P0, P1 and P2 were detected by immunobloting and the bands were quantified by densitometry. (D) The amount of P0, P1 and P2 mRNAs in the extracts was estimated by real time RT-PCR. The amount of P1 and P2 proteins (C) or mRNAs (D) were normalized to the respective levels of P0, which was not affected by Dox, and they were then expressed as a percentage of the values in control cells. The relative expression of mRNA in control cells were; P1/P0 10.4 \pm 5.8; P2/P0 0.7 \pm 0.3 . The bar graph shows the means of four independent experiments, and the standard deviation is indicated as error bars $( \pm \mathrm{SD})$. Statistical comparison was made using the Student's $t$ test for paired data, $* \mathrm{P}<0.05$.

Figure 2 Dox-induced P2 silencing reversibly reduces the growth of SP23-5 cells

(A) The cells were grown in the absence (, control) or the presence of $0.1 \mu \mathrm{g} / \mathrm{ml}(\mathbf{\square}), 1 \mu \mathrm{g} / \mathrm{ml}$ $(\boldsymbol{\Delta})$, or $10 \mu \mathrm{g} / \mathrm{ml}$ Dox $(\diamond)$ for 5 days, and the media was then replaced with normal media without Dox at various time points. Cells were counted in samples taken at the times indicated. (B) The doubling times (DT) were calculated from the induced cells (O) and from cells after removing Dox for 6 days ( $\mathbf{\square})$. The results shown are the average of three determinations with error bars showing the standard errors of the means. (C) Time-course of stalk P proteins expression. The protein extracted from the cells used to derive the growth curves in Figure 2A at $0.1 \mu \mathrm{g} / \mathrm{ml}$ (upper panel) or $10 \mu \mathrm{g} / \mathrm{ml}$ Dox (lower panel) were analysed by western blotting. The total days indicates the time from the start of the experiment as shown in Figure 2A. Treatment days correspond to the time from the beginning of each specific treatment indicated by an arrow in Figure 2A.

Figure 3 P2-silencing by Dox does not affect SP23-5 cell viability or their distribution throughout the cell cycle

(A) The viability of SP23-5 cells cultured in medium with different concentrations of Dox was evaluated. Cells were collected after each time point, stained with trypan blue and counted immediately. Samples were evaluated in triplicate with the standard errors shown. (B) The effect of P2 silencing on the distribution of cells throughout the cell cycle was evaluated. The cells were stained with propidium iodide and the DNA content was determined by flow cytometry to assess the proportion of cells in each phase of the cell cycle. Histograms and bars represent the mean and standard deviations of triplicate measurements.

Figure 4 Analysis of polysome profiles in P2-silenced cells

(A) Total extracts from SP23-5 cells before (control) and after exposure to $0.1 \mu \mathrm{g} / \mathrm{ml}$ Dox for 4 days were resolved on a $10-50 \%$ sucrose gradient. The position of free small (40S) and large $(60 \mathrm{~S})$ ribosomal subunits, monosomes (80S) and polysomes (2-8) are indicated. The arrows indicate the position of stalled preinitiation complexes (halfmers). (B) Fractions from the gradients shown in panel A were collected and the proteins were analyzed by immunoblotting. The position of proteins P0, P1 and P2 are indicated. (C) Translation efficiency in control and 
P1/P2-depleted cells. The overall translation efficiency was estimated as the relative amount of rRNA participating in polysomes. (D) Average number of ribosomes per mRNA in polysomes. These values were calculated by differential integration of the profiles in A. (E) The relative ribosome content was expressed as the ratio of total ribosomes (monosomes -80S- plus polysomes) to subunits (40S plus 60S). Data are the means \pm SD and the results were analyzed using the Student's t test for paired data, ${ }^{*} \mathrm{P}<0.05$.

\section{Figure 5 Analysis of ribosomal subunits in P2-silenced cells}

(A) Total ribosomes were isolated from control and Dox-induced P2 silenced cells $(0.1 \mu \mathrm{g} / \mathrm{ml}$ Dox for 4 days), dissociated into 40S and 60S subunits in the presence of $500 \mathrm{mM} \mathrm{KCl}$ and 5 $\mathrm{mM} \mathrm{MgCl}_{2}$, and then sedimented on a 10 to $30 \%$ sucrose gradient. (B) Sucrose gradient analysis of $\mathrm{Mg}^{2+}$-induced association of ribosomal subunits. Aliquots of ribosome preparation were fractionated on 10 to $30 \%$ sucrose gradient at the indicated $\mathrm{Mg}^{2+}$ concentrations and in the presence of $80 \mathrm{mM} \mathrm{KCl}$. The position of the 40S, 60S and 80S peaks are shown. (C) Subunit association (see Methods) from three experiments such as that shown in Figure 5B was plotted as a function of the $\mathrm{Mg}^{2+}$ concentration in control (white bars) and P2-silenced (black bars) cells. Data are the means \pm SD and the results were analyzed using the Student's t test for paired data, $* \mathrm{P}<0.05$. 
A
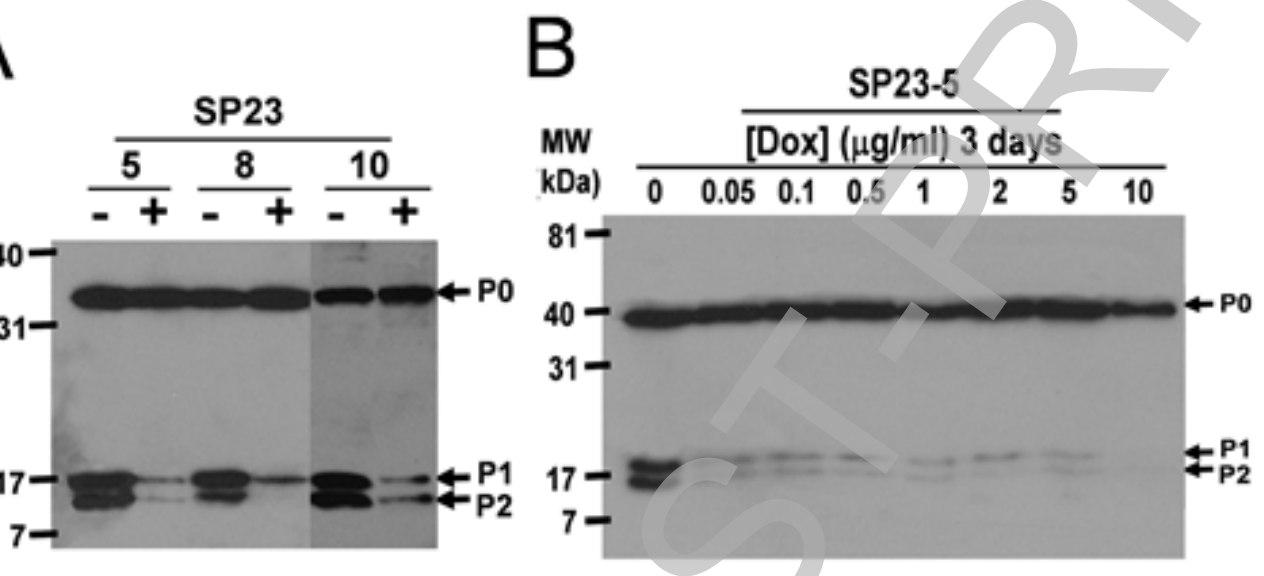

C

D
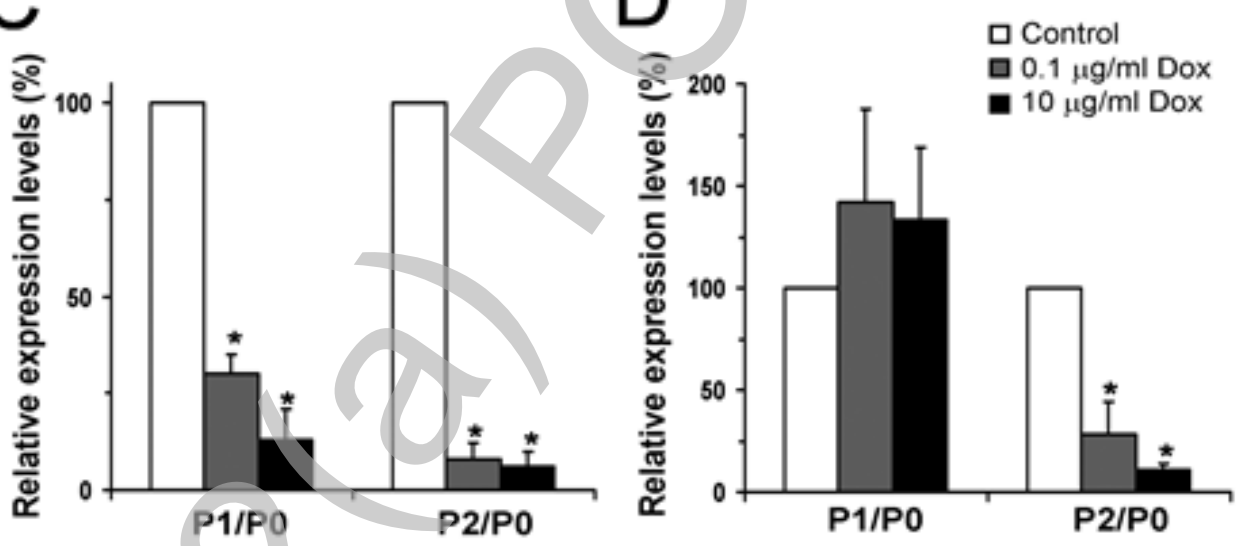

\section{Figure 1}

Licenced copy. Copying is not permitted, except with prior permission and as allowed by law. (C) 2008 The Authors Journal compilation (C) 2008 Biochemical Society 
Biochemical Journal Immediate Publication. Published on 18 Apr 2008 as manuscript BJ20080049
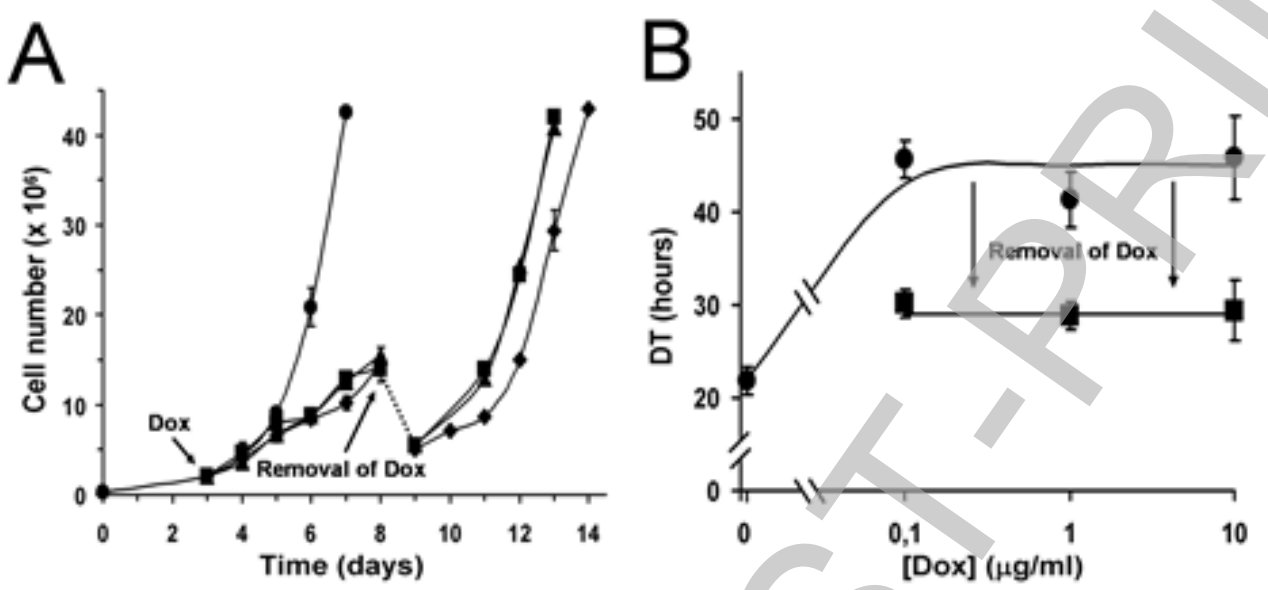

0
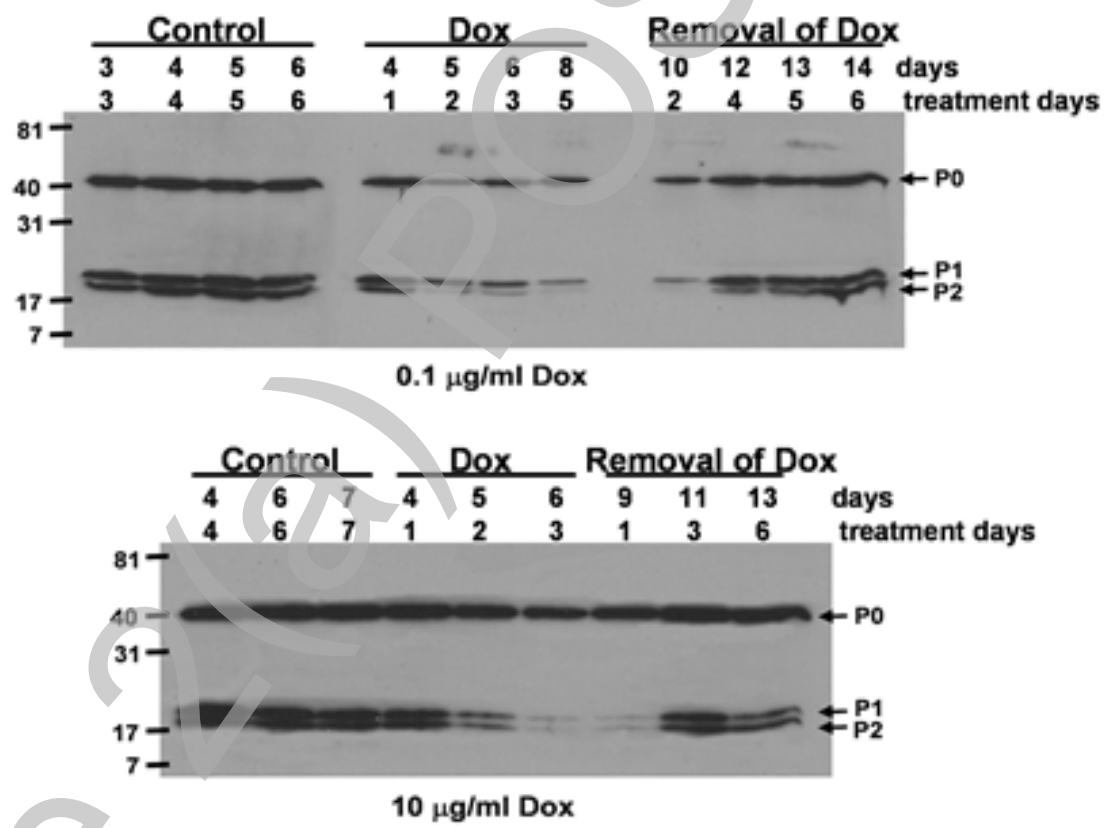

\section{Figure 2}

Licenced copy. Copying is not permitted, except with prior permission and as allowed by law. (C) 2008 The Authors Journal compilation (C) 2008 Biochemical Society 
B Biochemical Journal Immediate Publication. Published on 18 Apr 2008 as manuscript BJ20080049

A

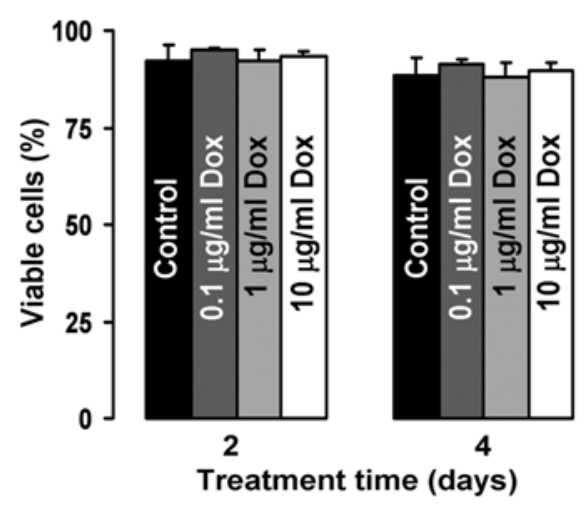

B

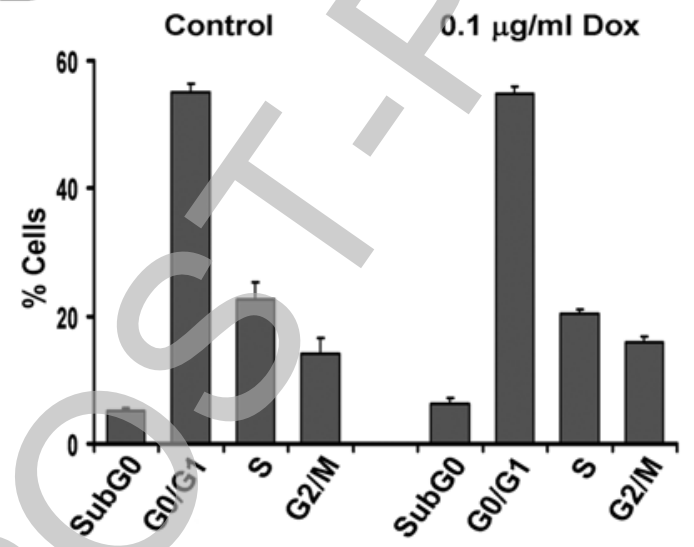

\section{Figure 3}



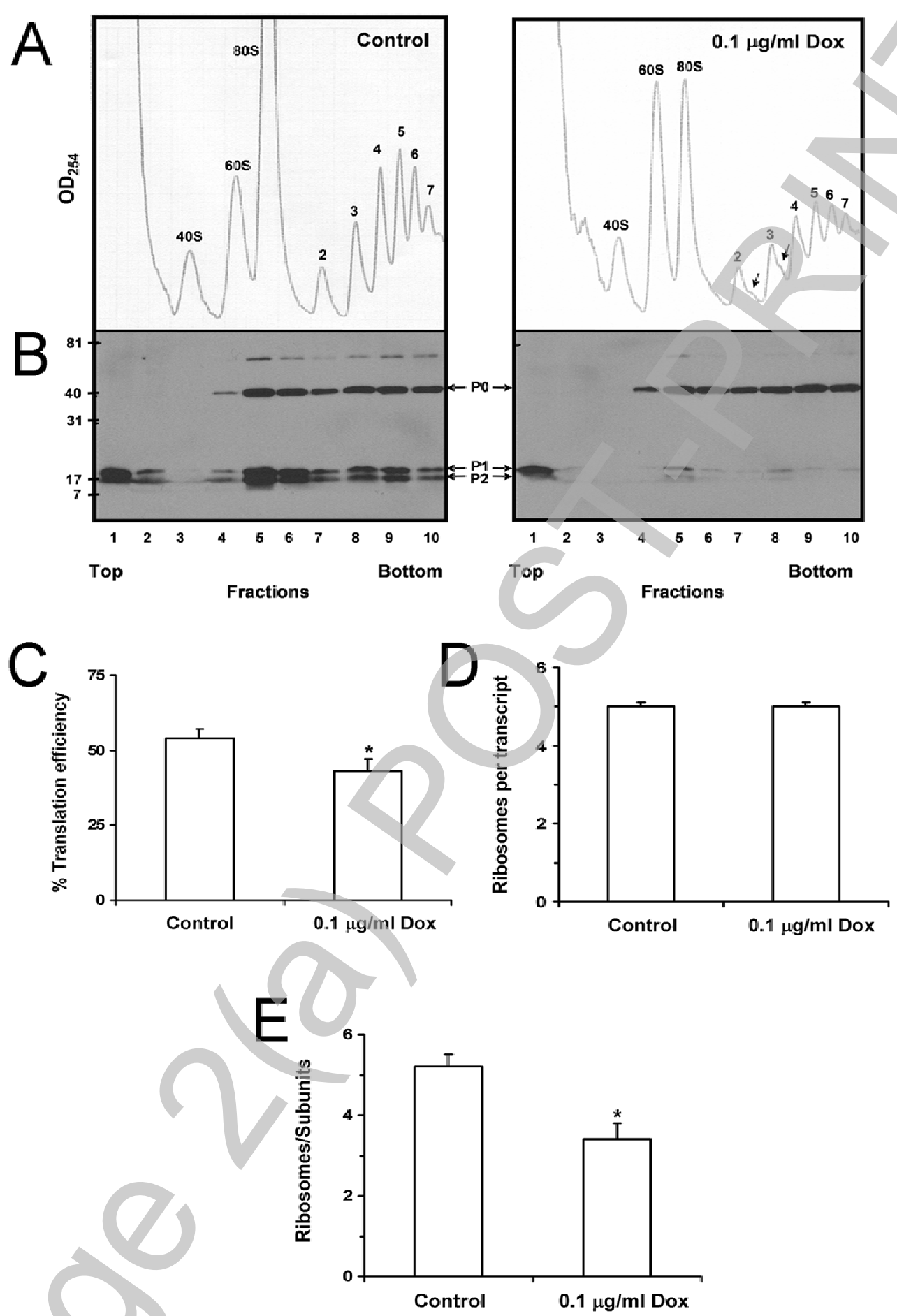

\section{Figure 4}

Licenced copy. Copying is not permitted, except with prior permission and as allowed by law. (C) 2008 The Authors Journal compilation (C) 2008 Biochemical Society 
A
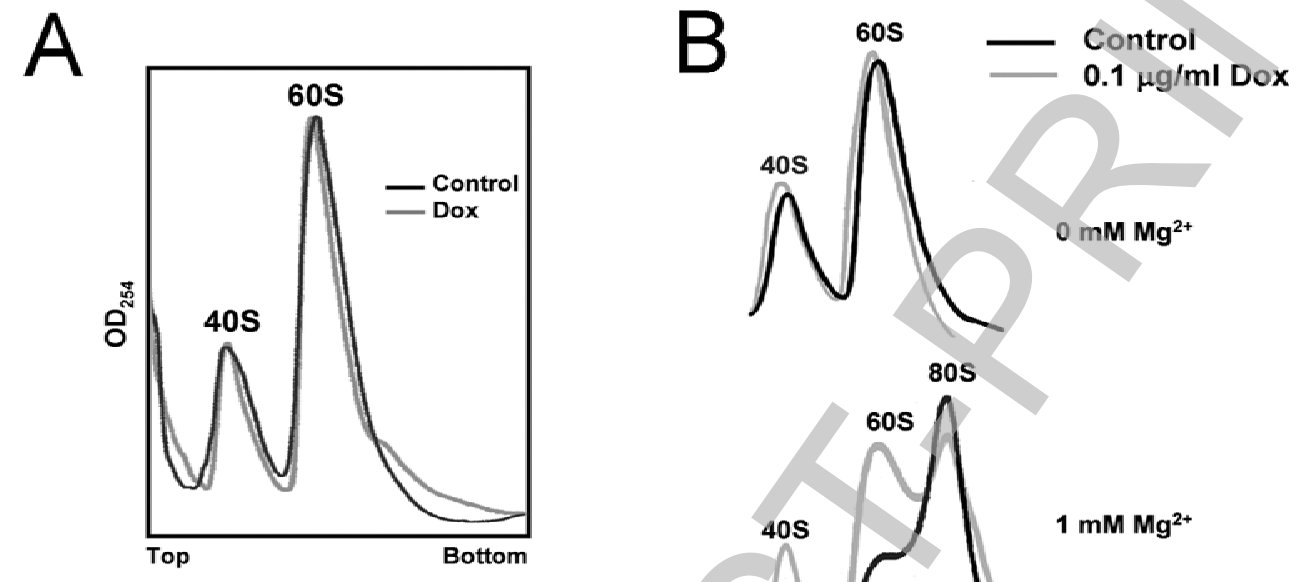
$0.1 \mu \mathrm{g} / \mathrm{ml}$ Dox

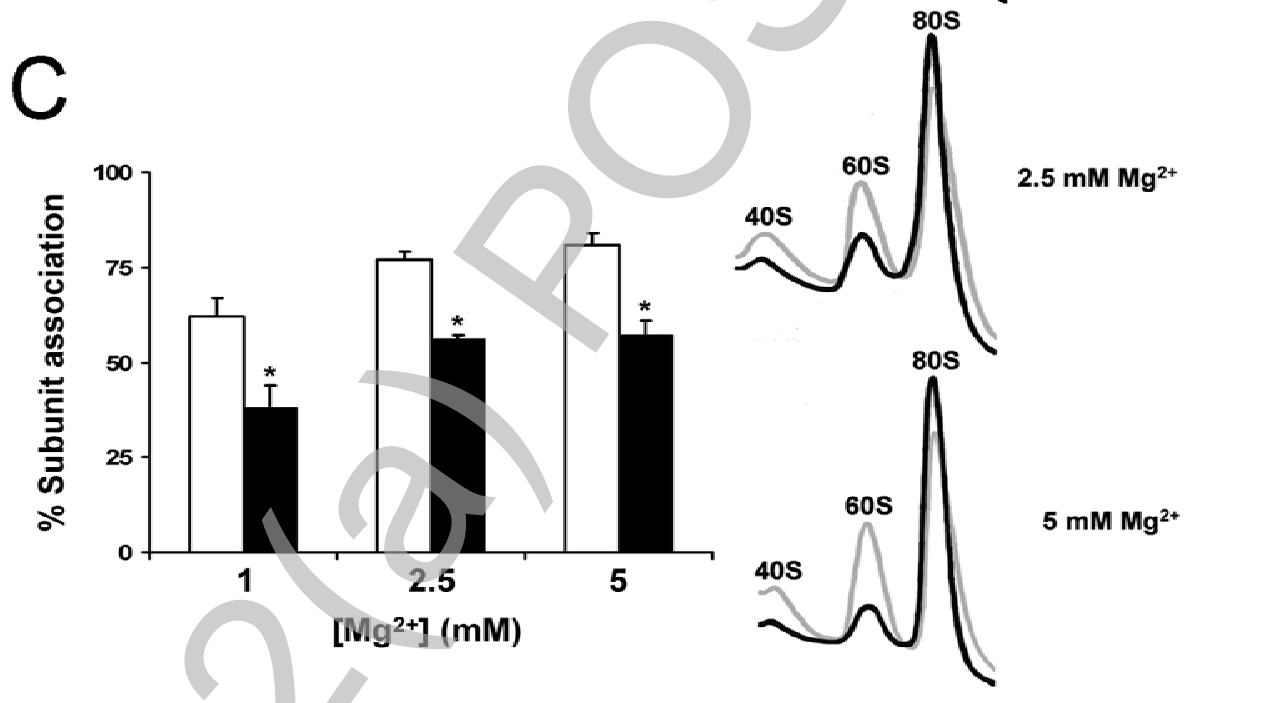

\section{Figure 5}

